\title{
Diterpenoid Alkaloids from the Aerial Parts of Aconitum flavum Hand.-Mazz
}

\author{
Na Zhang ${ }^{1,2} \cdot$ Fan Xia $^{1} \cdot$ Song-Yu Li ${ }^{1,2} \cdot$ Yin Nian ${ }^{1} \cdot$ Li-Xin Wei $^{3} \cdot$ Gang Xu ${ }^{1}(1)$
}

Received: 8 March 2021 / Accepted: 31 March 2021 / Published online: 16 April 2021

(c) The Author(s) 2021

\begin{abstract}
Sixteen diterpenoid alkaloids (DAs), including six aconitine-type alkaloids (5 and 9-13), seven 7,17-seco-aconitine-type alkaloids $(\mathbf{1 - 4 , 6 - 8})$, two napelline-type alkaloids $(\mathbf{1 4}$ and 15) as well as one veatchine-type alkaloid (16), were isolated from the aerial parts of Aconitum flavum Hand.-Mazz. In which, flavumolines A - D (1-4) were four new ones, and flavumoline E (5) was reported as natural compound for the first time. Their chemical structures were elucidated by the analysis of extensive spectroscopic data. The inhibitory activities of these isolates on $\mathrm{Ca}_{\mathrm{v}} 3.1$ low voltage-gated $\mathrm{Ca}^{2+}$ channel, $\mathrm{NO}$ production in LPS-activated RAW264.7cells, five human tumor cell lines, as well as acetylcholinesterase (AChE) were tested.
\end{abstract}

Keywords Aconitum flavum Hand.-Mazz · Diterpenoid alkaloids · Bioactivity

\section{Introduction}

Aconitum species represent a large genus in the Ranunclaceae family [1]. It is estimated that there are more than 350 species of Aconitum all over the world, which are widely distributed in the northern temperate zone, of which 173 species are endemic to mainland China [1]. Previously chemical and pharmacological studies shown that the diterpenoid alkaloids (DAs) were the main pharmacological constituents of this genus [2]. So far, around 1300 natural DAs, categorized into $\mathrm{C}_{20^{-}}, \mathrm{C}_{19^{-}}$, and $\mathrm{C}_{18^{-}}$families depending on the number of contiguous carbon atoms, have been reported [3], [4], [5]. Meanwhile, they have been the targets of medicinal chemists for a broad range of confirmed pharmacological properties including analgesic, antiarrhythmic,

Gang Xu

xugang008@mail.kib.ac.cn

1 State Key Laboratory of Phytochemistry and Plant Resources in West China and Yunnan Key Laboratory of Natural Medicinal Chemistry, Kunming Institute of Botany, Chinese Academy of Sciences, Kunming 650201, China

2 University of Chinese Academy of Sciences, Beijing 100049, China

3 Key Laboratory of Tibetan Medicine Research and Qinghai Provincial Key Laboratory of Tibetan Medicine Pharmacology and Safety Evaluation, Northwest Institute of Plateau Biology, Chinese Academy of Sciences, Xining, Qinghai, China anti-inflammatory, hypotensive, neuroprotective and so on [6].

Aconitum flavum Hand.-Mazz, known as a perennial herb, is mainly distributed in Qinghai, Gansu, and other northwest places in China [7]. As one of the most vital Chinese traditional ethnic minority folk medicine, the roots were commonly used for the treatment of traumatic injuries, rheumatic arthritis, and some other inflammations [7]. Previously phytochemical investigations of this plant have resulted in the isolation of more than 20 DAs from the roots, such as aconitine, mesaconitine, and deoxyaconitine, which were not only considered as the predominant toxic components of this folk medicine, but simultaneously, the significant active constituents [8]. In this study, sixteen DAs including four new 7,17-seco-aconitine-type DAs (flavumolines A-D, 1-4), one new natural compound (5), together with 11 known analogues (6-16) were identified. These compounds could be divided into four different types: six aconitines ( 5 and 9-13), seven 7,17-seco-aconitines (1-4 and 6-8), two napellines (14 and 15) as well as one veatchine-type alkaloid (16). All of these isolated compounds were evaluated for their inhibitory effects on $\mathrm{Ca}_{\mathrm{v}} 3.1$ low voltage-gated $\mathrm{Ca}^{2+}$ channel, NO production in LPS-activated RAW264.7 cells, five human tumor cell lines, and acetylcholinesterase (AChE). Reported herein, the isolation, structural determination, and biological activity of these compounds were thoroughly described. 


\section{Results and Discussion}

The $\mathrm{MeOH}$ extract was subjected to repeated column chromatography to yield four new ones (flavumolines A-D, 1-4), one new natural compound (5), together with 11 known analogues 13-hydroxylfranchetine (6) [9], vilmorisine (7) [10], franchetine (8) [11], 3-acetylaconitine (9) [12], 15-dehydroxyldecludine A (10) [13], pubescensine (11) [14], 3-O-acetyl-20-deethyl-20-formylaconitine (12) [15], $14 \alpha$-benzoyloxy- $N$-ethyl- $3 \alpha, 13 \beta, 15 \alpha$-trihydroxy$1 \alpha, 6 \alpha, 8 \beta, 16 \beta, 18$-pentamethoxyaconitane (13) [16], 15-acetylsongoramine (14) [17], dehydrolucidusculine (15) [18], and veatchine azomethine (16) [19].

Flavumoline A (1) was obtained as a white amorphous powder with the molecule formula as $\mathrm{C}_{29} \mathrm{H}_{35} \mathrm{NO}_{8}$ determined on the basis of HRESIMS at $\mathrm{m} / z$ 548.2259 $[\mathrm{M}+\mathrm{Na}]^{+}$(calcd for $\mathrm{C}_{29} \mathrm{H}_{35} \mathrm{NO}_{8} \mathrm{Na}, 548.2255$ ). The presence of hydroxyl $\left(3431 \mathrm{~cm}^{-1}\right)$ and carbonyl $\left(1672 \mathrm{~cm}^{-1}\right)$ units was deduced from the IR spectrum. The ${ }^{13} \mathrm{C}$ NMR and DEPT spectra displayed 29 carbons signals, which were divided into five methylenes, nine methines, and five quaternary carbons as well as the signals for a benzoyl and three methoxy groups. Detailly, the characterized signals for a franchetine-type $\mathrm{C}_{19}$-DA core could be distinguished as follows: one representative 6,17-epoxy unit (consisted of two oxygenated methines at $\delta_{\mathrm{C}} 83.1, \mathrm{C}-17$ and $\delta_{\mathrm{C}} 76.2$, C-6), two quaternary carbons at $\delta_{\mathrm{C}} 48.9(\mathrm{C}-4)$ and 51.0 (C-11), and three methines at $\delta_{\mathrm{C}} 46.5$ (C-5), 44.3 (C-9), and $47.1(\mathrm{C}-10)$, together with the typical C-7/C-8 trisubstituted double bond $\left(\delta_{\mathrm{C}} 128.0, \mathrm{~d}, \mathrm{C}-7\right.$ and $\delta_{\mathrm{C}} 137.4$, s, C-8) [3]. The ${ }^{1} \mathrm{H}$ NMR spectrum of $\mathbf{1}$ also verified resonances assignable to two oxygenated methines at $\delta_{\mathrm{H}} 4.62$ $(\mathrm{d}, J=4.6 \mathrm{~Hz}, \mathrm{H}-17)$ and $\delta_{\mathrm{H}} 4.71(\mathrm{~d}, J=6.1 \mathrm{~Hz}, \mathrm{H}-6)$, and a singlet at $\delta_{\mathrm{H}} 5.78(\mathrm{~d}, J=5.8 \mathrm{~Hz}, \mathrm{H}-7)$. These evidences, conjugated with the fact that a number of DAs have been reported as the major constituents of this genus, suggested that compound 1 was assigned to be a typical franchetine-type $\mathrm{C}_{19}$-DA [20]. This deduction could be further confirmed by the HMBC correlated signals of $\mathrm{H}-5$ with C-4/C-7/C-10/C-11/C-17/C-18/C-19, H-9 with C-12/C13/C-14, and H-10 with C-1/C-5/C-9/C-11/C-12/C-17. Furthermore, the 6,17-epoxy unit was confirmed by the correlations from $\mathrm{H}-17$ to $\mathrm{C}-6 / \mathrm{C}-11$ and $\mathrm{H}-6$ to $\mathrm{C}-5 / \mathrm{C}-$ 7/C-8/C-11/C-17. In addition, the correlations of H-3, H-5, $\mathrm{H}-17$, and $\mathrm{H}-18$ with $\mathrm{C}-19$, combined with correlations from $\mathrm{N}-\mathrm{H}\left(\delta_{\mathrm{H}} 6.29, \mathrm{~d}, J=4.7 \mathrm{~Hz}\right)$ to $\mathrm{C}-4 / \mathrm{C}-11 / \mathrm{C}-19 / \mathrm{C}-17$ confirmed the amide moiety between nitrogen atom and C-19 (Fig. 2).

Moreover, the benzoyl group was placed at C-14 according to the HMBC correlation from $\mathrm{H}-14\left(\delta_{\mathrm{H}} 5.07\right.$, s) to carbonyl $\left(\delta_{\mathrm{C}} 166.7, \mathrm{~s}\right)$. Three methoxy units were located at $\mathrm{C}-1, \mathrm{C}-16$, and $\mathrm{C}-18$ on the basis of the HMBC correlated signals from $\mathrm{OCH}_{3}-1\left(\delta_{\mathrm{H}} 3.41, \mathrm{~s}\right)$ to $\mathrm{C}-1\left(\delta_{\mathrm{C}}\right.$ $85.2, \mathrm{~d})$, from $\mathrm{OCH}_{3}-16\left(\delta_{\mathrm{H}} 3.50, \mathrm{~s}\right)$ to $\mathrm{C}-16\left(\delta_{\mathrm{C}} 85.8\right.$, d), and from $\mathrm{OCH}_{3}-18\left(\delta_{\mathrm{H}} 3.31, \mathrm{~s}\right)$ to $\mathrm{C}-18\left(\delta_{\mathrm{C}} 74.1, \mathrm{t}\right)$, respectively. Besides, a hydroxyl group should be located at $\mathrm{C}-13$ corresponding to the $\mathrm{HMBC}$ correlations from $\mathrm{OH}$ to $\mathrm{C}-12 / \mathrm{C}-13 / \mathrm{C}-16$.

Biogenetically, the configurations of $\mathrm{H}-5,9,10$, could be ascribed to $\beta$-orientation whereas $\mathrm{H}-17$ to $\alpha$-orientation, which could be confirmed by ROESY correlations of H-5/9/10/12 $\beta$ and H-17/12 $\alpha$, respectively [21]. Then, the $\alpha$-orientation of the benzoyl group at $\mathrm{C}-14$ was determined on the ROESY correlations between $\mathrm{H}-14$ and $\mathrm{H}-9$. And the $\alpha$-orientation of the $\mathrm{OCH}_{3}-1$ was identificated by the ROESY correlations between $\mathrm{H}-1 / \mathrm{H}-10$. In addition, the correlations of $\mathrm{H}-17 / \mathrm{H}-12 \alpha / \mathrm{H}-16$ and $13-\mathrm{OH} / \mathrm{H}-14$ demonstrated the $\beta$-orientation of $\mathrm{OCH}_{3}-16$ and 13-OH (Fig. 3, the dashed lines and solid lines to represent $\alpha$-orientation and $\beta$-orientation, respectively). Therefore, the structure of $\mathbf{1}$ was determined and named flavumoline A.

The molecular formula of compounds $2\left(\mathrm{C}_{30} \mathrm{H}_{37} \mathrm{NO}_{8}\right)$ and $3\left(\mathrm{C}_{31} \mathrm{H}_{41} \mathrm{NO}_{8}\right)$ were established on the analysis of HRESIMS and NMR data. The NMR data of $\mathbf{2}$ showed the presence of six methylenes, eight methines, three quaternary carbons, and a characteristic trisubstituted intra-annular double bond, in addition to a benzoyl, an aldehyde group and three methoxy groups. All of these spectroscopic data suggested that $\mathbf{2}$ was an analogue of 13-hydroxylfranchetine (6) [9]. The main difference was the presence of a $\mathrm{N}$-CHO moiety in compound $\mathbf{2}$ instead of $N$-ethyl group in $\mathbf{6}$, which was verified by $1 \mathrm{D}$ NMR data and HMBC correlations. The HMBC correlations (Fig. 2) from the singlet for aldehyde group $\left(\delta_{\mathrm{H}} 7.95\right.$, s) to $\mathrm{C}-19$ and $\mathrm{C}-17$ suggested that the aldehyde group was placed at $N$-atom. On the analysis of ROESY data, the correlations of $\mathrm{H}-14 / \mathrm{H}-9, \mathrm{H}-16 / \mathrm{H}-12 \alpha / \mathrm{H}-17$, $\mathrm{H}-1 / \mathrm{H}-10$ confirmed the $\alpha$-orientation of benzoyl group at $\mathrm{C}$-14, $\beta$-orientation of methoxy at C-16, and $\alpha$-orientation of methoxy at C-1, respectively. Compared with $\mathbf{2}$, compound 3 possessed a typical $N$-ethyl moiety, which were elucidated by the HMBC correlations from $\mathrm{H}-21$ to $\mathrm{C}-17, \mathrm{C}-19$. A hydroxyl located at $\mathrm{C}-3\left(\delta_{\mathrm{C}} 71.0, \mathrm{~d}\right)$ confirmed by the ${ }^{1} \mathrm{H}-{ }^{1} \mathrm{H}$ COSY correlation of $\mathrm{H}-2 / \mathrm{H}-3$ and HMBC correlations of $\mathrm{H}-3$ with C-2/5/19. Additionally, the ROESY correlations of $\mathrm{H}-3 / \mathrm{H}-1 / \mathrm{H}-5$ confirmed $\alpha$-orientation of $3-\mathrm{OH}$. Therefore, the structures of flavumoline B (2) and flavumoline C (3) were confirmed as shown above (Fig. 1).

Flavumoline D (4) was a colorless oily liquid with molecule formula of $\mathrm{C}_{31} \mathrm{H}_{41} \mathrm{NO}_{8}$ as deduced by analysis of the ion peak at $m / z 556.6689[\mathrm{M}+\mathrm{H}]^{+}$in the HRESIMS (calcd for $\mathrm{C}_{31} \mathrm{H}_{42} \mathrm{NO}_{8}, 556.6702$ ), which indicated 10 degrees of unsaturation. The ${ }^{13} \mathrm{C}$ NMR and DEPT data showed six methylenes, nine methines, four quaternary carbons, as well as the signals for a benzoyl group, three methoxy groups, and a typical $N$-ethyl group. Side by side, comparison of 


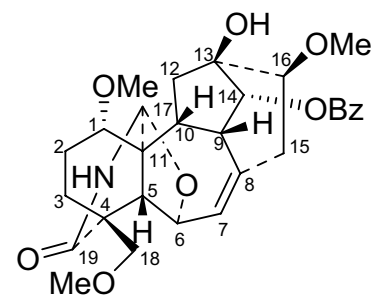

1

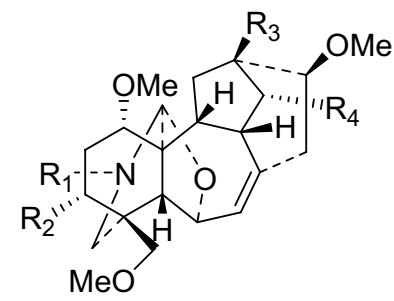

$2 \mathrm{R}_{1}=\mathrm{CHO} \quad \mathrm{R}_{2}=\mathrm{H} \quad \mathrm{R}_{3}=\mathrm{OH} \mathrm{R}_{4}=\mathrm{OBz}$

$3 \mathrm{R}_{1}=\mathrm{CH}_{2} \mathrm{CH}_{3} \mathrm{R}_{2}=\mathrm{OH} \mathrm{R}_{3}=\mathrm{OH} \mathrm{R}_{4}=\mathrm{OBz}$

$6 \mathrm{R}_{1}=\mathrm{CH}_{2} \mathrm{CH}_{3} \mathrm{R}_{2}=\mathrm{H} \quad \mathrm{R}_{3}=\mathrm{OH} \mathrm{R}_{4}=\mathrm{OBz}$

$7 \mathrm{R}_{1}=\mathrm{CH}_{2} \mathrm{CH}_{3} \quad \mathrm{R}_{2}=\mathrm{H} \quad \mathrm{R}_{3}=\mathrm{H} \quad \mathrm{R}_{4}=\mathrm{OAC}$

$8 \mathrm{R}_{1}=\mathrm{CH}_{2} \mathrm{CH}_{3} \quad \mathrm{R}_{2}=\mathrm{H} \quad \mathrm{R}_{3}=\mathrm{H} \quad \mathrm{R}_{4}=\mathrm{OBz}$

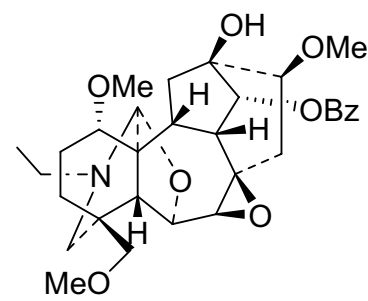

4

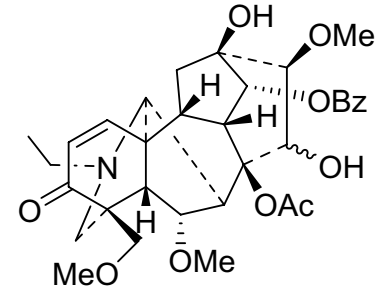

5

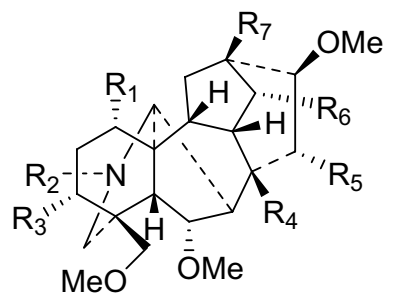

$9 \mathrm{R}_{1}=\mathrm{OMe} \mathrm{R}_{2}=\mathrm{CH}_{2} \mathrm{CH}_{3} \quad \mathrm{R}_{3}=\mathrm{OAc} \quad \mathrm{R}_{4}=\mathrm{OAc} \mathrm{R}_{5}=\mathrm{OH} \quad \mathrm{R}_{6}=\mathrm{OBz} \quad \mathrm{R}_{7}=\mathrm{OH}$

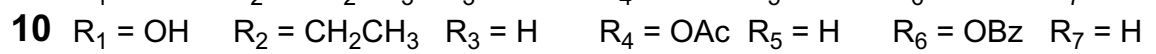

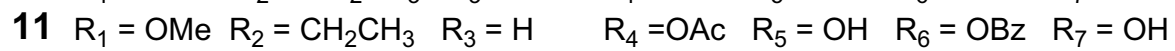

$12 \mathrm{R}_{1}=\mathrm{OMe} \mathrm{R}_{2}=\mathrm{CHO} \quad \mathrm{R}_{3}=\mathrm{OAc} \quad \mathrm{R}_{4}=\mathrm{OAc} \mathrm{R}_{5}=\mathrm{OAc} \mathrm{R}_{6}=\mathrm{OBz} \quad \mathrm{R}_{7}=\mathrm{OH}$

$13 \mathrm{R}_{1}=\mathrm{OMe} \mathrm{R} \mathrm{R}_{2}=\mathrm{CH}_{2} \mathrm{CH}_{3} \quad \mathrm{R}_{3}=\mathrm{OAc} \quad \mathrm{R}_{4}=\mathrm{OMe} \mathrm{R} \mathrm{R}_{5}=\mathrm{OH} \quad \mathrm{R}_{6}=\mathrm{OBz} \quad \mathrm{R}_{7}=\mathrm{OH}$

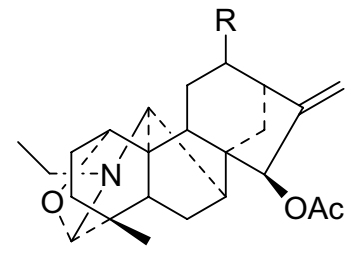

$14 \mathrm{R}=\mathrm{O}$

$15 \mathrm{R}=\alpha-\mathrm{OH}$

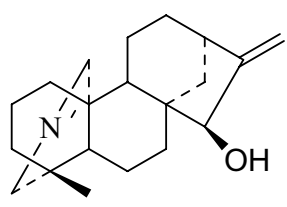

16

Fig. 1 Structures of compounds 1-16 from A. flavum Hand.-Mazz

its NMR data with those of $\mathbf{6}$, a known franchetine-type DA isolated previously, indicated that the structure of $\mathbf{4}$ was similar with that of 6 [9], except that the C-7/C-8 double bond was replaced by 7,8-epoxy unit $\left(\delta_{\mathrm{C}} 64.0, \mathrm{C}-7\right.$ and $\delta_{\mathrm{C}}$ 59.0, C-8). The HMBC correlations of $\mathrm{H}-5 / \mathrm{H}-15$ with $\mathrm{C}-7$ and $\mathrm{H}-7 / \mathrm{H}-9 / \mathrm{H}-10 / \mathrm{H}-15$ with $\mathrm{C}-8$ confirmed the 7,8-epoxy unit. In addition, the remained three methoxy groups, one hydroxyl, and one benzoyl were elucidated to be attached on $\mathrm{C}-1, \mathrm{C}-16, \mathrm{C}-18, \mathrm{C}-13$, and $\mathrm{C}-14$, respectively, as deduced by the $\mathrm{HMBC}$ correlations of $\mathrm{OCH}_{3}-1\left(\delta_{\mathrm{H}} 3.35, \mathrm{~s}\right)$ with $\mathrm{C}-1$ $\left(\delta_{\mathrm{C}} 86.0, \mathrm{~d}\right), \mathrm{OCH}_{3}-16\left(\delta_{\mathrm{H}} 3.42, \mathrm{~s}\right)$ with $\mathrm{C}-16\left(\delta_{\mathrm{C}} 82.6, \mathrm{~d}\right)$, $\mathrm{OCH}_{3}-18\left(\delta_{\mathrm{H}} 3.30, \mathrm{~s}\right)$ with C-18 $\left(\delta_{\mathrm{C}} 79.0, \mathrm{t}\right)$, hydroxyl group $\left(\delta_{\mathrm{H}} 3.92, \mathrm{~s}\right)$ with C-12/C-13/C-16, and $\mathrm{H}-14\left(\delta_{\mathrm{H}} 5.11\right.$, d,
$J=3.0 \mathrm{~Hz})$ with the carbonyl $\left(\delta_{\mathrm{C}} 166.7, \mathrm{~s}\right)$ of the benzoyl group (Fig. 2).

The relative configuration of $\mathbf{4}$ was confirmed by the analysis of ROESY spectrum. At first, the correlation from H-14 to $\mathrm{H}-9$ implied the benzoyl group at $\mathrm{C}-14$ was $\alpha$-oriented. The configurations of methoxyl groups were confirmed as $1 \alpha-\mathrm{OCH}_{3}$ and $16 \beta-\mathrm{OCH}_{3}$ on account of the correlations of $\mathrm{H}-1 / \mathrm{H}-10$ and $\mathrm{H}-16 / \mathrm{H}-12 \alpha / \mathrm{H}-17$. Then, the remained hydroxyl group at $\mathrm{C}-13$ was established as $\beta$-oriented according to its correlation with $16-\mathrm{OCH}_{3}$. On the basis of correlations of $\mathrm{H}-7 / \mathrm{H}-15 \alpha / \mathrm{H}-16$, the configuration of 7,8epoxy unit was identified as $\beta$-orientation (Fig. 3). Hence, the structure of $\mathbf{4}$ was established as above. 


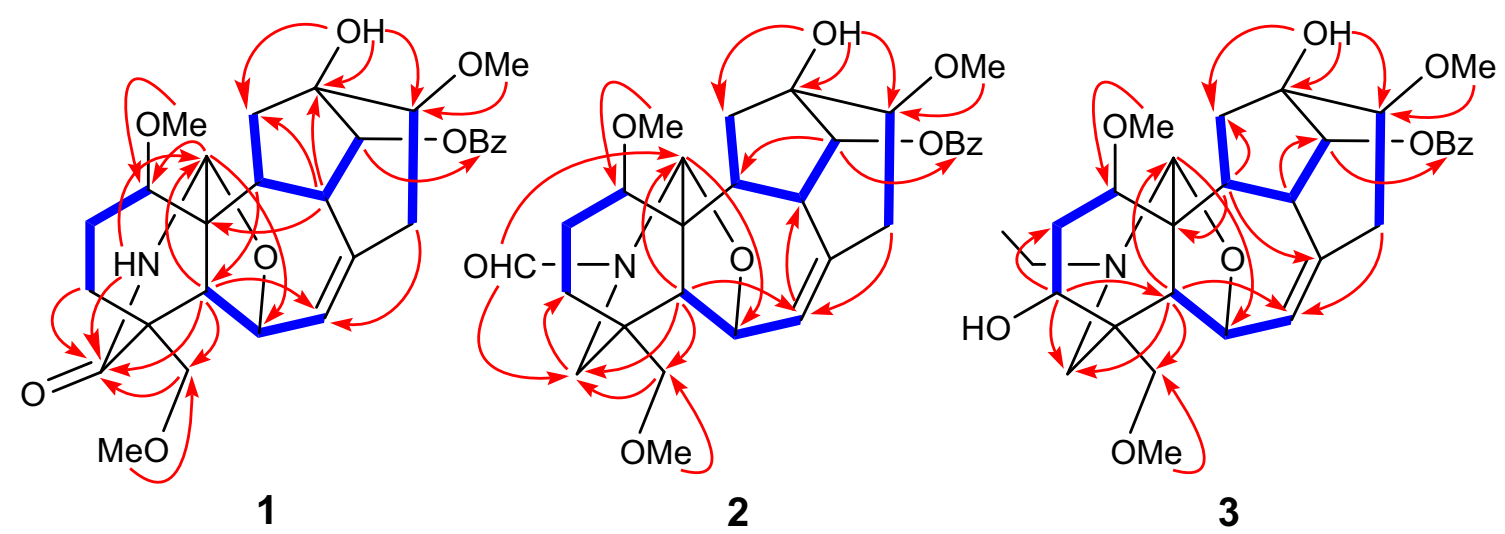

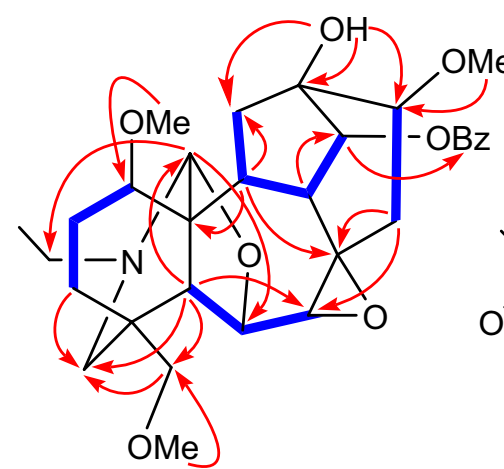

4

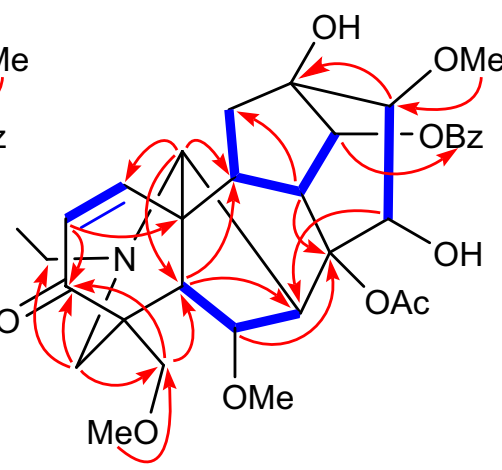

5

Fig. 2 Key ${ }^{1} \mathrm{H}-{ }^{1} \mathrm{H}$ COSY and HMBC correlations of compounds $\mathbf{1}-\mathbf{5}$
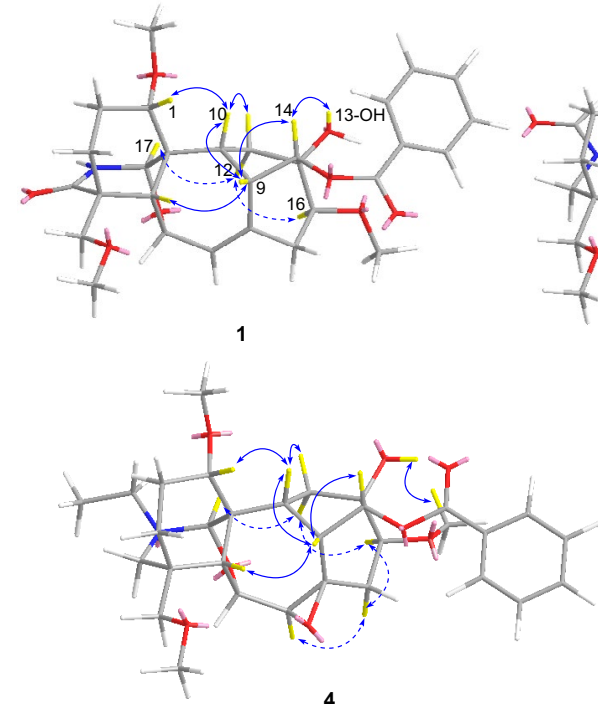

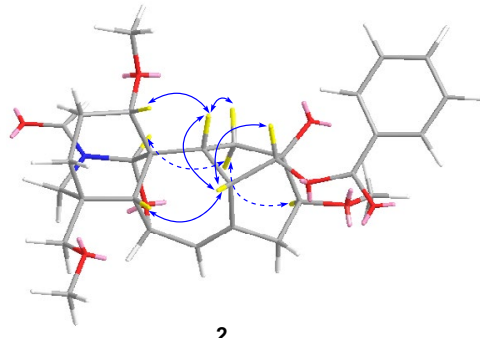

2

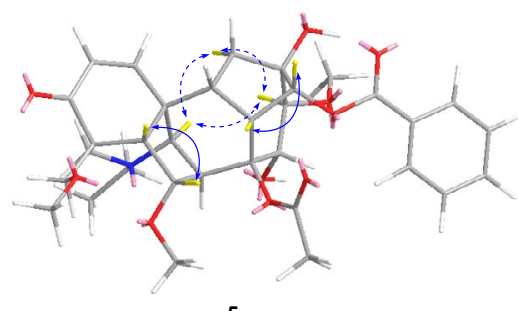

$\Longrightarrow$ Key ROESY correlations

Fig. 3 Key ROESY correlations of compounds 1 -5

Flavumoline $\mathrm{E}(\mathbf{5})$, was isolated as white amorphous powder. Its molecular formula was established as $\mathrm{C}_{33} \mathrm{H}_{41} \mathrm{NO}_{10}$ on the basis of HRESIMS at $\mathrm{m} / \mathrm{z} 612.2799[\mathrm{M}+\mathrm{H}]^{+}$ (calcd for $\mathrm{C}_{33} \mathrm{H}_{42} \mathrm{NO}_{10}, 612.2803$ ), in combination with
NMR spectroscopic data. The IR spectrum of $\mathbf{5}$ showed absorptions due to the hydroxyl $\left(3487 \mathrm{~cm}^{-1}\right)$ and carbonyl $\left(1676 \mathrm{~cm}^{-1}\right)$ functionalities. The ${ }^{13} \mathrm{C}$ NMR and DEPT spectra of $\mathbf{5}$ displayed 33 carbon resonances including five 
quaternary carbons (one carbonyl at $\delta_{\mathrm{C}} 200.5, \mathrm{~s}, \mathrm{C}-3$, two oxygenated carbons at $\delta_{\mathrm{C}} 92.1, \mathrm{C}-8$ and $\left.\delta_{\mathrm{C}} 74.3, \mathrm{C}-13\right)$, eleven methines, three methylenes, and 14 other signals attributable to a benzoyl, a typical $N$-ethyl group, an acetoxyl, and three methoxy groups. By carefully analyzing the characteristic resonances of a $N$-ethyl group at $\delta_{\mathrm{C}} 49.2$, t $(\mathrm{C}-21)$ and $\delta_{\mathrm{C}} 13.2, \mathrm{q}(\mathrm{C}-22)$, a nitrogen-bearing methine and methylene at $\delta_{\mathrm{C}} 60.8, \mathrm{~d}(\mathrm{C}-17)$ and $\delta_{\mathrm{C}} 51.0, \mathrm{t}(\mathrm{C}-19)$, an $\alpha, \beta$-unsaturated ketone moiety at $\delta_{\mathrm{H}} 6.27,6.46$ (each $1 \mathrm{H}, \mathrm{d}, J=10.3 \mathrm{~Hz}$ ) together with the C-atom signals at $\delta_{\mathrm{C}}$ $132.3,147.3$, and 200.5 were clearly observed. The ${ }^{1} \mathrm{H}$ NMR spectrum also verified resonances assignable to a nitrogenbearing methine and methylene at $\delta_{\mathrm{H}} 2.76(\mathrm{~s}, \mathrm{H}-17), \delta_{\mathrm{H}} 2.62$ (d, $J=11.4 \mathrm{~Hz}, \mathrm{H}-19 \mathrm{a}$ ) and 2.38 (overlap, $\mathrm{H}-19 \mathrm{~b}$ ), as well as a representative $N$-ethyl group at $\delta_{\mathrm{H}} 2.39,2.69(\mathrm{~m}, \mathrm{H}-21)$ and $\delta_{\mathrm{H}} 1.00(\mathrm{t}, J=7.1 \mathrm{~Hz}, \mathrm{H}-22)$. These evidences suggested that 5 should be a typical aconitine-type $\mathrm{C}_{19}$-DA [22]. This deduction could be further confirmed by the HMBC correlations of $\mathrm{H}-17$ with $\mathrm{C}-5 / \mathrm{C}-6 / \mathrm{C}-8 / \mathrm{C}-10 / \mathrm{C}-11 / \mathrm{C}-19, \mathrm{H}-19$ with C-3/C-4/C-5/C-17/C-18/C-21, H-5 with C-4/C-7/C-10/C11/C-17/C-18/C-19, H-9 with C-8/C-12/C-13/C-14/C-15, H-10 with C-8/C-9/C-12/C-13/C-17, toghther with the connection of $\mathrm{C}-17, \mathrm{C}-19$, and $\mathrm{C}-21$ to the same nitrogen atom evidenced by the HMBC correlations from $\mathrm{H}-19$ to $\mathrm{C}-17$ and C-21, from $\mathrm{H}-21$ to $\mathrm{C}-17$ and C-19 (Fig. 2).

According to the $\mathrm{HMBC}$ spectrum, the correlations between one $\mathrm{OH}$ group $\left(\delta_{\mathrm{H}} 4.01, \mathrm{~s}\right)$ and $\mathrm{C}-12 / \mathrm{C}-13 / \mathrm{C}-16$, another $\mathrm{OH}$ group $\left(\delta_{\mathrm{H}} 4.47, \mathrm{~d}, J=3.0 \mathrm{~Hz}\right)$ and $\mathrm{C}-13 / \mathrm{C}$ $15 / \mathrm{C}-16, \mathrm{OAc}\left(\delta_{\mathrm{H}} 1.45, \mathrm{~s}\right)$ and C-8, H-14 $\left(\delta_{\mathrm{H}} 4.98, \mathrm{~d}\right.$, $J=5.0 \mathrm{~Hz})$ and carbonyl of benzoyl group, identified the location of these substituent groups at C-13, C-15, C-8, and $\mathrm{C}-14$, respectively. Additionally, the substitutions of $6-\mathrm{OCH}_{3}, 16-\mathrm{OCH}_{3}$, and $18-\mathrm{OCH}_{3}$ were identified by the correlations from $\mathrm{OCH}_{3}-6$ to $\mathrm{C}-6, \mathrm{OCH}_{3}-16$ to $\mathrm{C}-16, \mathrm{OCH}_{3}-18$ to $\mathrm{C}-18$. The $\mathrm{HMBC}$ correlated resonances between $\mathrm{H}-1$ and C-10/C-17, H-2 and C-4/C-11, H-18a,b/H-19a,b and C-3, demonstrated that the $\mathrm{C}=\mathrm{C}$ bond was located between $\mathrm{C}-1$ and C-2 and the carbonyl group at C-3 (200.5, s).

Biosynthetically, the configurations of H-5, 9, 10, 8-OAc, $13-\mathrm{OH}$ could be ascribed to $\beta$-orientation and $\mathrm{H}-17$ to $\alpha$-orientation, respectively, due to the caged core of aconitine-type $\mathrm{C}_{19}$-DA [23]. Then, the configurations of two methoxy groups and one benzoyl at C-6, 16, and 14 were confirmed as $\alpha, \beta$, and $\alpha$, respectively, according to the correlations between $\mathrm{H}-6 / \mathrm{H}-5, \mathrm{H}-16 / \mathrm{H}-12 \alpha / \mathrm{H}-17$ and $\mathrm{H}-14 / \mathrm{H}-9$ (Fig. 3). However, the configuration of $15-\mathrm{OH}$ has not been confirmed yet because of the simultaneous correlations of $\mathrm{H}-15$ with $\mathrm{H}-7 / \mathrm{H}-16 / 16-\mathrm{OCH}_{3}$ and $15-\mathrm{OH}$ with $\mathrm{H}-7 / \mathrm{H}-$ $16 / 16-\mathrm{OCH}_{3}$. Eventually, the structure of 5 was identified as shown in Fig. 1, which was reported as a natural compound for the first time according to the literature on synthesis [24].

Since diterpenoid alkaloids in Aconitum were reported to commonly treat traumatic injury, arrhythmia, and rheumatism, in which ion channels or inflammation were involved in the pathophysiological process and inhibitors of ion channels or NO release were considered as potential agents for the treatment of these diseases [25], these isolated compounds were evaluated for their inhibitory effects on T-type ion channels using the whole-cell recording patch clamp method, NO production in LPS-activated RAW264.7 cells using Griess assay [26], on five human tumor cell lines [27], as well as acetylcholinesterase (AChE) [28]. As a result, compound $8(30 \mu \mathrm{M})$ exhibited $64.5 \%$ inhibitory rate on $\mathrm{Ca}_{\mathrm{v}} 3.1$ low voltage-gated $\mathrm{Ca}^{2+}$ channel. Compounds $\mathbf{3}$, $4,5,6,7$, and 11 showed potential inhibitory effects on NO production ranging from $20 \%$ to $32 \%$ at $50 \mu \mathrm{M}$. Additionally, compound $\mathbf{5}$ showed potential inhibitory effects on four human tumor cell lines HL-60, A-549, SMMC-7721, MCF-7 with $\mathrm{IC}_{50}$ value as $16.88,33.11,23.97,24.21 \mu \mathrm{M}$ in vitro, and no compound showed inhibitory effect on AChE.

\section{Experimental}

\subsection{General Experimental Procedures}

Optical rotations were measured on a Jasco P-1020 polarimeter. UV spectra were detected on a Shmadzu UV-2401PC spectrometer. IR spectra were determined on a Bruker FT-IR Tensor-27 infrared spectrophotometer with $\mathrm{KBr}$ disks. All 1D and 2D NMR spectra were recorded on Bruker DRX-600 spectrometers using TMS as an internal standard. Unless otherwise specified, chemical shifts $(\delta)$ were expressed in ppm with reference to the solvent signals. ESIMS and HRESIMS analysis were carried out on Waters Xevo TQS and Aglient G6230 TOF mass spectrometers, respectively. Semi-preparative HPLC was performed on a Waters 2695 HPLC with a $5 \mathrm{C}_{18}$-MS-II column [4.6×150 mm]. Silica gel (100-200, 200-300 mesh, Qingdao Marine Chemical Co., Ltd., People's Republic of China), and MCI gel (75-150 $\mu \mathrm{m}$, Mitsubishi Chemical Corporation, Tokyo, Japan) were used for column chromatography. Fractions were monitored by TLC (GF 254, Qingdao Marine Chemical Co., Ltd.), and spots were visualized under a UV lamp at $254 \mathrm{~nm}$ or by spraying the Dragendorff' reagent and heating silica gel plates sprayed with $10 \% \mathrm{H}_{2} \mathrm{SO}_{4}$ in $\mathrm{EtOH}$.

\subsection{Plant Material}

The plants of A. flavum were collected in June 2019 from the Sanjiangyuan Nature Reserve of Guoluo, Qinghai Province, People's Republic of China. Plant identity was verified by prof. Li-Xin Wei. A voucher specimen (No. 201901H19) was deposited in the Kunming Institute of Botany. 


\subsection{Extraction and Isolation}

Air-dried and powdered plant material (aerial parts) of A. flavum $(45 \mathrm{~kg})$ was extracted three times $(3 \times 150 \mathrm{~L})$ with $\mathrm{MeOH}$ at room temperature and then concentrated to $3.88 \mathrm{~kg}$ under reduce pressure. The crude extract was suspended in $1 \% \mathrm{HCl}$ followed by basification with $10 \%$ aqueous $\mathrm{NH}_{4} \mathrm{OH}$ (pH 9-10) and subsequently, extracted with ethyl acetate to afford crude alkaloids $(808 \mathrm{~g})$. The total alkaloids fraction was separated on a silica gel column $\left(\mathrm{CHCl}_{3} / \mathrm{CH}_{3} \mathrm{OH}, 100: 1-1: 1\right)$ to yield eight fractions (Fr. $1-8)$. Then Fr. $1(35 \mathrm{~g})$ was separated on a silica gel column (PE/EtOAc/DEA, 50:1:1 - 3:1:1) to yield six sub-fractions (Fr. 1a-1f). Fr. 1a (2.3 g) was separated on a silica gel column (PE/EtOAc, 80:1-3:1) and then semipreparative HPLC (Waters $2695 \mathrm{C} 18$, i.d. $150 \times 10 \mathrm{~mm}$, $5 \mu \mathrm{m}, 3.0 \mathrm{ml} / \mathrm{min}$, UV $210 \mathrm{~nm})$ using $\mathrm{MeOH} / \mathrm{H}_{2} \mathrm{O}(85 / 15$, $\mathrm{v} / \mathrm{v})$ as the mobile phase afforded $6(57 \mathrm{mg}), \mathbf{7}(10 \mathrm{mg})$ and $\mathbf{8}(23 \mathrm{mg})$. Fr. $1 \mathrm{~b}(2.7 \mathrm{~g})$ was separated on a silica gel column (PE/EtOAc, 60:1-3:1) followed by preparative $\mathrm{HPLC}$ using $\mathrm{MeOH} / \mathrm{H}_{2} \mathrm{O}(75 / 25, \mathrm{v} / \mathrm{v})$ to yield 4 (128 mg), $14(15 \mathrm{mg}), \mathbf{1 5}(9.7 \mathrm{mg})$ and $\mathbf{1 6}(6 \mathrm{mg})$. Fr. 1c $(3 \mathrm{~g})$ was separated on a silica gel column (PE/EtOAc, 50:1-3:1), followed by semi-preparative HPLC using $\mathrm{MeOH} / \mathrm{H}_{2} \mathrm{O}$ $(70 / 30, v / v)$ as the mobile phase to afford $\mathbf{1 0}(8 \mathrm{mg}), \mathbf{1 1}$ $(3 \mathrm{mg})$ and then yield $9(230 \mathrm{mg})$ by recrystallizaiton. Fr. $1 \mathrm{~d}(7 \mathrm{~g})$ was separated on a silica gel column (PE/ EtOAc, 50:1-1:1) yielded $12(50 \mathrm{mg})$ and then on semipreparative HPLC using $\mathrm{MeOH} / \mathrm{H}_{2} \mathrm{O}(70 / 30$, v/v) as the mobile phase to afford $\mathbf{1 3}(10 \mathrm{mg})$. Fr. $1 \mathrm{e}(5.5 \mathrm{~g})$ yielded $2(7.3 \mathrm{mg})$ and $\mathbf{3}(20.1 \mathrm{mg})$ by preparative HPLC using $\mathrm{MeOH} / \mathrm{H}_{2} \mathrm{O}(70 / 25, \mathrm{v} / \mathrm{v})$ as mobile phase, subsequently, afforded $\mathbf{5}(4.7 \mathrm{mg})$ and $\mathbf{1}(2 \mathrm{mg})$ isolated by Sephadex II column using acetone.

\subsubsection{Flavumoline A (1)}

White powder; $[\alpha]_{\mathrm{D}}^{19}-4.9(c 0.175, \mathrm{MeOH}) ; \mathrm{IR}(\mathrm{KBr}) \nu_{\max }$ : 3431, 2975, 2933, 2828, 1718, 1672, 1282, $1099 \mathrm{~cm}^{-1}$; For ${ }^{13} \mathrm{C}$ NMR data (see Table 1) and ${ }^{1} \mathrm{H}$ NMR data (see Table 2). ESIMS $m / z 526[\mathrm{M}+\mathrm{H}]^{+}$; HRESIMS $m / z$ : $548.2259[\mathrm{M}+\mathrm{Na}]^{+}$(calcd for $\mathrm{C}_{29} \mathrm{H}_{35} \mathrm{NO}_{8} \mathrm{Na}, 548.2255$ ).

\subsubsection{Flavumoline B (2)}

White powder; $[\alpha]_{\mathrm{D}}^{18}-12.5(c 0.100, \mathrm{MeOH})$; IR $(\mathrm{KBr})$ $\nu_{\max }: 3447,2938,2882,2828,1717,1670,1280$, $1099 \mathrm{~cm}^{-1}$; For ${ }^{13} \mathrm{C}$ NMR data (see Table 1) and ${ }^{1} \mathrm{H}$ NMR data (see Table 2). ESIMS $m / z 540[\mathrm{M}+\mathrm{H}]^{+}$; HRESIMS $m / z: 562.2408[\mathrm{M}+\mathrm{Na}]^{+}$(calcd for $\mathrm{C}_{30} \mathrm{H}_{37} \mathrm{NO}_{8} \mathrm{Na}$, 562.2411).
Table $1{ }^{13} \mathrm{C}$ NMR (150 MHz) spectroscopic data for compounds $\mathbf{1}-\mathbf{5}$ (in $\mathrm{CDCl}_{3}$ )

\begin{tabular}{|c|c|c|c|c|c|}
\hline No & 1 & 2 & 3 & 4 & 5 \\
\hline 1 & 85.2 & 85.1 & 83.9 & 86.0 & 147.3 \\
\hline 2 & 25.1 & 23.6 & 33.0 & 24.2 & 132.3 \\
\hline 3 & 31.0 & 32.3 & 71.0 & 32.4 & 200.5 \\
\hline 4 & 48.9 & 36.5 & 42.0 & 36.9 & 49.3 \\
\hline 5 & 46.5 & 46.8 & 45.2 & 43.0 & 48.6 \\
\hline 6 & 76.2 & 76.5 & 74.6 & 76.0 & 82.5 \\
\hline 7 & 128.0 & 127.9 & 128.9 & 64.0 & 45.1 \\
\hline 8 & 137.4 & 137.4 & 136.0 & 59.0 & 92.1 \\
\hline 9 & 44.3 & 44.0 & 43.9 & 44.3 & 43.3 \\
\hline 10 & 47.1 & 47.6 & 46.6 & 44.4 & 37.6 \\
\hline 11 & 51.0 & 51.3 & 50.3 & 49.1 & 51.1 \\
\hline 12 & 38.6 & 38.8 & 38.8 & 38.5 & 38.2 \\
\hline 13 & 77.3 & 77.2 & 77.3 & 76.8 & 74.3 \\
\hline 14 & 83.0 & 83.0 & 83.4 & 82.8 & 79.1 \\
\hline 15 & 39.1 & 39.0 & 39.0 & 36.9 & 78.9 \\
\hline 16 & 85.8 & 85.7 & 85.9 & 82.6 & 90.2 \\
\hline 17 & 83.1 & 86.9 & 92.1 & 94.4 & 60.8 \\
\hline 18 & 74.1 & 77.6 & 75.8 & 79.0 & 72.0 \\
\hline 19 & 174.9 & 41.9 & 45.5 & 52.2 & 51.0 \\
\hline 21 & - & 160.7 & 49.0 & 49.0 & 49.2 \\
\hline 22 & - & - & 13.0 & 13.0 & 13.2 \\
\hline $1-\mathrm{OCH}_{3}$ & 57.3 & 57.0 & 57.1 & 57.1 & - \\
\hline $6-\mathrm{OCH}_{3}$ & - & - & - & - & 58.5 \\
\hline $16-\mathrm{OCH}_{3}$ & 58.2 & 58.1 & 58.1 & 58.1 & 61.6 \\
\hline $18-\mathrm{OCH}_{3}$ & 59.5 & 59.5 & 59.5 & 59.5 & 59.3 \\
\hline$-\mathrm{OBz}$ & 166.7 & 166.7 & 166.7 & 166.7 & 166.1 \\
\hline $1^{\prime}$ & 130.1 & 130.0 & 130.2 & 130.0 & 129.7 \\
\hline $2^{\prime}, 6^{\prime}$ & 129.8 & 129.8 & 129.8 & 129.8 & 129.8 \\
\hline $3^{\prime}, 5^{\prime}$ & 128.5 & 128.5 & 128.5 & 128.4 & 129.0 \\
\hline $4^{\prime}$ & 133.2 & 133.2 & 133.1 & 133.2 & 133.7 \\
\hline \multirow[t]{2}{*}{ 8-OAc } & - & - & - & - & 172.6 \\
\hline & - & - & - & - & 21.6 \\
\hline
\end{tabular}

\subsubsection{Flavumoline C (3)}

White powder; $[\alpha]_{\mathrm{D}}^{18}-9.7(c 0.103, \mathrm{MeOH})$; IR $(\mathrm{KBr}) \nu_{\max }$ : 3534, 3402, 2974, 2824, 1717, 1280, $1103 \mathrm{~cm}^{-1}$; For ${ }^{13} \mathrm{C}$ NMR data (see Table 1) and ${ }^{1} \mathrm{H}$ NMR data (see Table 2). ESIMS $m / z 556[\mathrm{M}+\mathrm{H}]^{+}$; HRESIMS $m / z: 556.2905$ $[\mathrm{M}+\mathrm{H}]^{+}$(calcd for $\left.\mathrm{C}_{31} \mathrm{H}_{42} \mathrm{NO}_{8} \mathrm{Na}, 556.2905\right)$.

\subsubsection{Flavumoline D (4)}

Colorless oily liquid; $[\alpha]_{\mathrm{D} 19}^{19}-3.9(c 0.101, \mathrm{MeOH})$; IR $(\mathrm{KBr}) \nu_{\max }: 3437,2973,2932,2826,1719,1279,1101 \mathrm{~cm}^{-1}$; For ${ }^{13} \mathrm{C}$ NMR data (see Table 1 ) and ${ }^{1} \mathrm{H}$ NMR data (see Table 2). ESIMS $m / z 556[\mathrm{M}+\mathrm{H}]^{+}$; HRESIMS $\mathrm{m} / z$ : $556.6689[\mathrm{M}+\mathrm{H}]^{+}\left(\right.$calcd for $\left.\mathrm{C}_{31} \mathrm{H}_{42} \mathrm{NO}_{8}, 556.6702\right)$. 
Table $2{ }^{1} \mathrm{H}$ NMR $(600 \mathrm{MHz})$ spectroscopic data for compounds $\mathbf{1}-\mathbf{5}\left(\right.$ in $\left.\mathrm{CDCl}_{3}\right)$

\begin{tabular}{|c|c|c|c|c|c|}
\hline No & $1(\mathrm{~J}$ in $\mathrm{Hz})$ & $2(\mathrm{~J}$ in $\mathrm{Hz})$ & $3(J$ in $\mathrm{Hz})$ & $4(J$ in $\mathrm{Hz})$ & $5(J$ in $\mathrm{Hz})$ \\
\hline 1 & $3.58 \mathrm{~m}$ & $3.52 \mathrm{~m}$ & $3.38 \mathrm{~m}$ & $3.21 \mathrm{~m}$ & $6.46 \mathrm{~d}(10.3)$ \\
\hline 2 & $\begin{array}{l}2.20 \mathrm{~m} \\
1.74 \mathrm{~m}\end{array}$ & $\begin{array}{l}2.05 \mathrm{~m} \\
1.52 \mathrm{~m}\end{array}$ & $\begin{array}{l}2.52 \mathrm{~m} \\
2.22 \mathrm{~m}\end{array}$ & $\begin{array}{l}2.38 \mathrm{~m} \\
1.93 \mathrm{~m}\end{array}$ & $6.27 \mathrm{~d}(10.3)$ \\
\hline 3 & $\begin{array}{l}1.83 \mathrm{~m} \\
1.78 \mathrm{~m}\end{array}$ & $\begin{array}{l}1.79 \mathrm{~m} \\
1.60 \mathrm{~m}\end{array}$ & $3.85 \mathrm{dd}(4.9$ 12.3) & $\begin{array}{l}1.80 \mathrm{~m} \\
1.44 \mathrm{~m}\end{array}$ & - \\
\hline 4 & - & - & - & - & - \\
\hline 5 & $2.68 \mathrm{~m}$ & $2.47 \mathrm{~s}$ & $2.19 \mathrm{~s}$ & $1.82 \mathrm{~s}$ & $3.11 \mathrm{~d}(6.4)$ \\
\hline 6 & $4.71 \mathrm{~d}(6.1)$ & $4.69 \mathrm{~d}(6.0)$ & $4.39 \mathrm{~d}(6.1)$ & $4.58 \mathrm{~d}(4.5)$ & $4.11 \mathrm{~d}(6.4)$ \\
\hline 7 & $5.78 \mathrm{~d}(5.8)$ & $5.77 \mathrm{~d}(5.76)$ & $5.76 \mathrm{~d}(5.8)$ & $2.90 \mathrm{~d}(4.2)$ & 3.04 br s \\
\hline 8 & - & - & - & - & - \\
\hline 9 & $3.28 \mathrm{br} \mathrm{s}$ & 3.25 br s & 3.14 br s & $2.70 \mathrm{~m}$ & $2.98 \mathrm{~m}$ \\
\hline 10 & $2.73 \mathrm{~m}$ & $2.71 \mathrm{~m}$ & $2.60 \mathrm{~m}$ & $2.56 \mathrm{~m}$ & $2.37 \mathrm{~m}$ \\
\hline 11 & - & - & - & - & - \\
\hline 12 & $\begin{array}{l}2.14 \mathrm{~m} \\
2.07 \mathrm{~m}\end{array}$ & $\begin{array}{l}2.20 \mathrm{~m} \\
2.00 \mathrm{~m}\end{array}$ & $\begin{array}{l}2.08 \mathrm{~m} \\
1.99 \mathrm{~m}\end{array}$ & $\begin{array}{l}2.58 \text { overlap } \\
2.21 \mathrm{~m}\end{array}$ & $\begin{array}{l}2.44 \mathrm{~m} \\
1.74 \mathrm{~m}\end{array}$ \\
\hline 13 & - & - & - & - & - \\
\hline 14 & $5.07 \mathrm{~s}$ & 5.06 br s & 5.01 br s & $5.11 \mathrm{~d}(3.0)$ & $4.98 \mathrm{~d}(5.0)$ \\
\hline 15 & $\begin{array}{l}2.99 \mathrm{~m} \\
2.70 \mathrm{~m}\end{array}$ & $\begin{array}{l}2.98 \mathrm{~m} \\
2.69 \text { overlap }\end{array}$ & $\begin{array}{l}2.92 \mathrm{~m} \\
2.62 \mathrm{~m}\end{array}$ & $\begin{array}{l}2.78 \mathrm{~m} \\
1.68 \mathrm{~m}\end{array}$ & $4.54 \mathrm{dd}(2.75 .3)$ \\
\hline 16 & $3.35 \mathrm{~m}$ & $3.37 \mathrm{~m}$ & $3.31 \mathrm{~m}$ & $3.46 \mathrm{~m}$ & $3.31 \mathrm{~d}(5.4)$ \\
\hline 17 & $4.62 \mathrm{~d}(4.6)$ & $4.96 \mathrm{~s}$ & $4.35 \mathrm{~s}$ & $4.49 \mathrm{br} \mathrm{s}$ & $2.76 \mathrm{~s}$ \\
\hline 18 & $\begin{array}{l}3.68 \mathrm{~d}(9.7) \\
3.60 \mathrm{~d}(9.7)\end{array}$ & $\begin{array}{l}3.22 \mathrm{~d}(9.4) \\
3.10 \mathrm{~d}(9.4)\end{array}$ & $\begin{array}{l}3.32 \text { overlap } \\
3.17 \mathrm{~d}(9.4)\end{array}$ & 3.09 br s & $\begin{array}{l}3.91 \mathrm{~d}(8.5) \\
3.65 \mathrm{~d}(8.5)\end{array}$ \\
\hline 19 & $\begin{array}{l}- \\
-\end{array}$ & $\begin{array}{l}3.74 \mathrm{~d}(13.7) \\
2.66 \text { overlap }\end{array}$ & $\begin{array}{l}2.87 \mathrm{~d}(11.3) \\
1.73 \mathrm{~d}(11.3)\end{array}$ & $\begin{array}{l}2.52 \text { overlap } \\
2.11 \mathrm{~d}(11.3)\end{array}$ & $\begin{array}{l}2.62 \mathrm{~d}(11.4) \\
2.38 \text { overlap }\end{array}$ \\
\hline 21 & - & $7.95 \mathrm{~s}$ & $\begin{array}{l}2.57 \mathrm{~m} \\
2.38 \mathrm{~m}\end{array}$ & $\begin{array}{l}2.65 \mathrm{~m} \\
2.48 \mathrm{~m}\end{array}$ & $\begin{array}{l}2.69 \mathrm{~m} \\
2.39 \text { overlap }\end{array}$ \\
\hline 22 & - & - & $1.01 \mathrm{t}(7.3)$ & $1.05 \mathrm{t}(7.3)$ & $1.00 \mathrm{t}(7.1)$ \\
\hline $1-\mathrm{OCH}_{3}$ & $3.41 \mathrm{~s}$ & $3.33 \mathrm{~s}$ & $3.34 \mathrm{~s}$ & $3.35 \mathrm{~s}$ & - \\
\hline $6-\mathrm{OCH}_{3}$ & - & - & - & - & $3.22 \mathrm{~s}$ \\
\hline $16-\mathrm{OCH}_{3}$ & $3.50 \mathrm{~s}$ & $3.51 \mathrm{~s}$ & $3.44 \mathrm{~s}$ & $3.42 \mathrm{~s}$ & $3.77 \mathrm{~s}$ \\
\hline $18-\mathrm{OCH}_{3}$ & $3.31 \mathrm{~s}$ & $3.28 \mathrm{~s}$ & $3.28 \mathrm{~s}$ & $3.30 \mathrm{~s}$ & $3.27 \mathrm{~s}$ \\
\hline $2^{\prime}, 6^{\prime}$ & $8.10 \mathrm{~d}(7.6)$ & $8.08 \mathrm{~d}(7.8)$ & $8.05 \mathrm{~d}(7.8)$ & $8.08 \mathrm{~d}(7.6)$ & $8.04 \mathrm{~d}(7.4)$ \\
\hline $3^{\prime}, 5^{\prime}$ & $7.47 \mathrm{t}(7.6)$ & $7.47 \mathrm{t}(7.8)$ & $7.43 \mathrm{t}(7.8)$ & $7.48 \mathrm{t}(7.6)$ & $7.48 \mathrm{t}(7.4)$ \\
\hline $4^{\prime}$ & $7.59 \mathrm{t}(7.6)$ & $7.59 \mathrm{t}(7.8)$ & $7.55 \mathrm{t}(7.8)$ & $7.58 \mathrm{t}(7.6)$ & $7.60 \mathrm{t}(7.4)$ \\
\hline $15-\mathrm{OH}$ & - & - & - & - & $4.47 \mathrm{~d}(3.0)$ \\
\hline $13-\mathrm{OH}$ & $3.95 \mathrm{~s}$ & $3.93 \mathrm{~s}$ & $3.89 \mathrm{~s}$ & $3.92 \mathrm{~s}$ & $4.01 \mathrm{~s}$ \\
\hline $\mathrm{N}-\mathrm{H}$ & $6.29 \mathrm{~d}(4.7)$ & - & - & - & - \\
\hline $\mathrm{CHO}$ & - & $7.95 \mathrm{~s}$ & - & - & - \\
\hline 8-OAc & - & - & - & - & $1.45 \mathrm{~s}$ \\
\hline
\end{tabular}

\subsubsection{Flavumoline E (5)}

White powder; $[\alpha]_{\mathrm{D}}^{18}+4.4(c 0.122, \mathrm{MeOH})$; IR $(\mathrm{KBr})$ $\nu_{\max }: 3487,2973,2936,1721,1676,1280 \mathrm{~cm}^{-1}$; For ${ }^{13} \mathrm{C}$ NMR data (see Table 1) and ${ }^{1} \mathrm{H}$ NMR data (see Table 2). ESIMS $m / z 612[\mathrm{M}+\mathrm{H}]^{+}$; HRESIMS $\mathrm{m} / z 612.2799$ $[\mathrm{M}+\mathrm{H}]^{+}$(calcd for $\mathrm{C}_{33} \mathrm{H}_{42} \mathrm{NO}_{10}, 612.2803$ ).

\section{Bioassays}

\subsection{T-Type Ion Channel Inhibitory Activity Assay}

All experiments were performed at room temperature $\left(\sim 22{ }^{\circ} \mathrm{C}\right)$. Pipettes were fabricated from borosilicate glass 
(World Precision Instru-ments) using a micropipette puller (P-1000, Sutter Instrument), and were fire-polished to resistances of 2 4 $\mathrm{M}$ for whole-cell recording. Wholecell currents were elicited by $150 \mathrm{~ms}$ depolarization to $-40 \mathrm{mV}$ at $4 \mathrm{~s}$ intervals from a holding potential (HP) of $-100 \mathrm{mV}$. Currents were amplified by Axopatch 200B and digitized by Digidata 1440A (Molecular Devices). Currents were low-pass filtered at $2 \mathrm{kHz}$ and sampled at $10 \mathrm{kHz}$. pCLAMP 10 software (Molecular Devices) was used for data acquisition and analysis. The extracellular solutions contained (in mM) $142 \mathrm{CsCl}, 1 \mathrm{MgCl}_{2}, 2 \mathrm{CaCl}_{2}$, 10 Glucose and 10 HEPES (pH 7.4 adjusted with $\mathrm{CsOH}$ ). The intracellular solutions contained (in mM) 127 Csmethanesulphonate, $2 \mathrm{MgCl}_{2}, 2 \mathrm{Na}_{2} \mathrm{ATP}, 10$ HEPES and 11 EGTA ( $\mathrm{pH} 7.4$ adjusted with $\mathrm{CsOH}$ ). The tested compounds $(30 \mu \mathrm{M})$ were added.

\subsection{Anti-Inflammatory Activity Assay}

The murine macrophage cell line RAW264.7 was obtained from Cell Bank of Chinese Academy of Sciences. RAW264.7 cells were seeded in 96-well cell culture plates $\left(1.5 \times 10^{5}\right.$ cells/well $)$ and treated with serial dilutions of the compounds with a maximum concentration of $50 \mu \mathrm{M}$ in triplicate, followed by stimulation with $1 \mu \mathrm{g} / \mathrm{mL}$ LPS (Sigma) for $18 \mathrm{~h}$. NO production in the supernatant was assessed by Griess reagents (Sigma). The absorbance at $570 \mathrm{~nm}$ was measured with a microplate reader (Thermo, Waltham, MA, USA). $\mathrm{N}^{\mathrm{G}}$-Methyl-L-arginine acetate salt (L-NMMA, Sigma) was used as a positive control [29]. The viability of RAW264.7 cells was evaluated by the MTS assay simultaneously to exclude the interference of the cytotoxicity of the test compounds.

\subsection{Cytotoxicity Assay}

The human tumor cell lines HL-60, SMMC-7721, A-549, MCF-7, and SW-480 were obtained from ATCC (Manassas, VA, USA). Cells were cultured in RMPI-1640 or DMEM medium (Biological Industries, Kibbutz Beit-Haemek, Israel) supplemented with $10 \%$ fetal bovine serum (Biological Industries) at $37{ }^{\circ} \mathrm{C}$ in a humidified atmosphere with $5 \% \mathrm{CO}_{2}$. The cytotoxicity assay was evaluated by the 3-(4,5-dimethylthiazol-2-yl)-5-(3-carboxymethoxyphenyl)2-(4-sulfophenyl)-2H-tetrazolium, inner salt (MTS) (Promega, Madison, WI, USA) assay [30]. Briefly, cells were seeded into each well of a 96-well cell culture plate. After $12 \mathrm{~h}$ of incubation at $37{ }^{\circ} \mathrm{C}$, the test compound $(40 \mu \mathrm{M})$ was added. After incubated for $48 \mathrm{~h}$, cells were subjected to the MTS assay. Compounds with a growth inhibition rate of $50 \%$ were further evaluated at concentrations of 0.064 , $0.32,1.6,8$, and $40 \mu \mathrm{M}$ in triplicate, with cisplatin and paclitaxel (Sigma, St. Louis, MO, USA) as positive controls. The
$\mathrm{IC}_{50}$ value of each compound was calculated with Reed and Muench's method [31].

\subsection{AChE Inhibitory Activity Assay}

Acetylcholinesterase (AChE) inhibitory activity of the compounds isolated was assayed by the spectrophotometric method developed by Ellman et al.[32] with slightly modification. $S$-Acetylthiocholine iodide, $S$-butyrylthiocholine iodide, 5,5'-dithio-bis-(2-nitrobenzoic) acid (DTNB, Ellmans' reagent), acetylcholinesterase derived from human erythrocytes were purchased from Sigma Chemical. Compounds were dissolved in DMSO. The reaction mixture (totally $200 \mu \mathrm{L}$ ) containing phosphate buffer (pH 8.0), test compound $(50 \mu \mathrm{M})$, and acetyl cholinesterase $(0.02 \mathrm{U} / \mathrm{mL})$, was incubated for $20 \min \left(37^{\circ} \mathrm{C}\right)$. Then, the reaction was initiated by the addition of $40 \mu \mathrm{L}$ of solution containing DTNB $(0.625 \mathrm{mM})$ and acetylthiocholine iodide $(0.625 \mathrm{mM})$ for AChE inhibitory activity assay, respectively. The hydrolysis of acetylthiocholine was monitored at $405 \mathrm{~nm}$ every $30 \mathrm{~s}$ for one hour. Tacrine was used as positive control with final concentration of $0.333 \mu \mathrm{M}$. All the reactions were performed in triplicate. The percentage inhibition was calculated as follows: $(\%)$ inhibition $=(\mathrm{E}-\mathrm{S}) / \mathrm{E} \times 100(\mathrm{E}$ is the activity of the enzyme without test compound and $\mathrm{S}$ is the activity of enzyme with test compound).

Supplementary Information The online version contains supplementary material available at https://doi.org/10.1007/s13659-021-00302-3.

Acknowledgements The work was financially supported by the Second Tibetan Plateau Scientific Expedition and Research (STEP) program (2019QZKK0502), State Key Laboratory of Phytochemistry and Plant Resources in West China (P2017-KF02 and P2019-ZZ05), and the Natural Sciences Foundation of Yunnan Province (2019FA003).

\section{Declarations}

Conflict of interest All authors declare no conflict of interest.

Open Access This article is licensed under a Creative Commons Attribution 4.0 International License, which permits use, sharing, adaptation, distribution and reproduction in any medium or format, as long as you give appropriate credit to the original author(s) and the source, provide a link to the Creative Commons licence, and indicate if changes were made. The images or other third party material in this article are included in the article's Creative Commons licence, unless indicated otherwise in a credit line to the material. If material is not included in the article's Creative Commons licence and your intended use is not permitted by statutory regulation or exceeds the permitted use, you will need to obtain permission directly from the copyright holder. To view a copy of this licence, visit http://creativecommons.org/licenses/by/4.0/. 


\section{References}

1. G.Y. Jiang, L.L. Qin, F. Gao, S. Huang, X.L. Zhou, Fitoterapia 141, 104738 (2020)

2. R.P. Zhang, Y.J. Lin, H.F. Yu, S.Y. Chen, J. Zhou, Nat. Prod. Bioprospect. 10, 105-108 (2020)

3. F.P. Wang, Q.H. Chen, X.Y. Liu, Nat. Prod. Rep. 27, 529-570 (2010)

4 Z.Q. Mu, H. Gao, Z.Y. Huang, Org. Lett. 14, 2758-2761 (2012)

5 J.F. Zhang, L. Chen, S. Huang, J. Nat. Prod. 80, 3136-3142 (2017)

6. F.Z. Chen, D.L. Chen, Q.H. Chen, F.P. Wang, J. Nat. Prod. 72, 18-23 (2009)

7. T. Wang, D.H. Xu, H.Y. Xu, P. Sheng, Lishizhen. Med. Mater. Med. Res. 19, 2162-2163 (2008). ((in Chinese))

8. J. Wang, X.H. Meng, T. Chai, J.L. Yang, Y.P. Shi, Nat. Prod. Bioprospect. 9, 419-423 (2019)

9. F. Zhang, S.L. Peng, F. Luo, L.S. Ding, Chin. Chem. Lett. 16, 1043-1046 (2005)

10. B. Zhao, J.Y. Zhao, ShSh. Sagdullaev, H.A. Aisa, Chem. Nat. Compd. 54, 828-830 (2018)

11. D.H. Chen, W.L. Song, Acta Chim. Sinica 41, 843-846 (1983)

12. Y.Q. He, B.H. Yao, Z.Y. Ma, J. Phar. Anal. 1, 57-59 (2011)

13. T.P. Yin, L. Cai, G. Lei, J.W. Dong, Chin. J. Org. Chem. 33, 2528-2532 (2013)

14. L. Chen, L.H. Shan, J.F. Zhang, W.L. Xu, M.Y. Wu, S. Huang, X.L. Zhou, Nat. Prod. Commun. 12, 2063-2065 (2015)

15. Y. Shen, A.X. Zuo, Z.Y. Jiang, X.M. Zhang, H.L. Wang, J.J. Chen, Helv. Chim. Acta. 93, 863-868 (2010)

16. X.X. Zong, X.J. Yan, J.L. Wu, Z.Q. Liu, H. Zhou, N. Li, L. Liu, J. Nat. Prod. 82, 980-989 (2019)

17. F. Gao, Y.Y. Li, D. Wang, X. Huang, Q. Liu, Molecules 17, $5187-$ $5194(2012)$
18. H. Yamashita, K. Takeda, M. Haraguchi, Y. Abe, N. Kuwahara, S. Suzuki, A. Terui, T. Masaka, N. Munakata, M. Uchida, M. Nunokawa, K. Kaneda, M. Goto, K.H. Lee, K. Wada, J. Nat. Med. 72, 230-237 (2018)

19. S. William Pelletier, D.M. Locke, J. Am. Chem. Soc. 87, 761-776 (1965)

20. Y. Si, X. Ding, T.A. Adelakuna, Y. Zhang, X.J. Hao, Fitoterapia 147, 104738 (2020)

21. H. Cheng, F.H. Zeng, D. Ma, M.L. Jiang, L. Xu, F.P. Wang, Org. Lett. 16, 2299-2301 (2014)

22. F.L. Wen, Y.Y. Jiang, H. Tang, D.L. Chen, F.P. Wang, Nat Prod Commun. 12, 329-330 (2017)

23. F. Shaheen, M. Zeeshan, M. Ahmad, S. Anjum, S. Ali, H.K. Fun, M.I. Choudhary, A. Rahman, J. Nat. Prod. 69, 823-825 (2006)

24. X.K. She, X.X. Jian, D.L. Chen, Q.H. Chen, F.P. Wang, J. Asian. Nat. Prod. Res. 14, 665-677 (2012)

25. F. Wang, Z.G. Yue, P. Xie, L. Zhang, Z. Li, B. Song, Z.S. Tang, X.M. Song, Molecules 21, 1175 (2016)

26. V.M. Dirsch, H. Stuppner, A.M. Vollmar, Planta Med. 64, 423$426(1998)$

27. K. Wada, H. Yamashita, Molecules 24, 2317 (2019)

28. H. Ahmad, S. Ahmad, M. Ali, A. Latif, H. Naz, N. Rahman, F. Shaheen, A. Wadood, H.U. Khan, M. Ahmad, Bioorg. Chem. 78, 427-435 (2018)

29. D.W. Reif, S.A. Mc Creedy, Arch, Biochem. Biophys. 1, 170-176 (1995)

30. A.H. Cory, Cancer Commun. 3, 207-212 (1991)

31. L.J. Reed, H. Muench, Am. J. Trop. Med. Hyg. 27, 493-497 (1938)

32. G.L. Ellman, K.D. Courtney, V.J. Andres, R.M. Featherstone, Biochem. Pharmacol. 7, 88-95 (1961) 